\title{
レオロジーのシミュレーション
}

\section{Rheology Simulations}

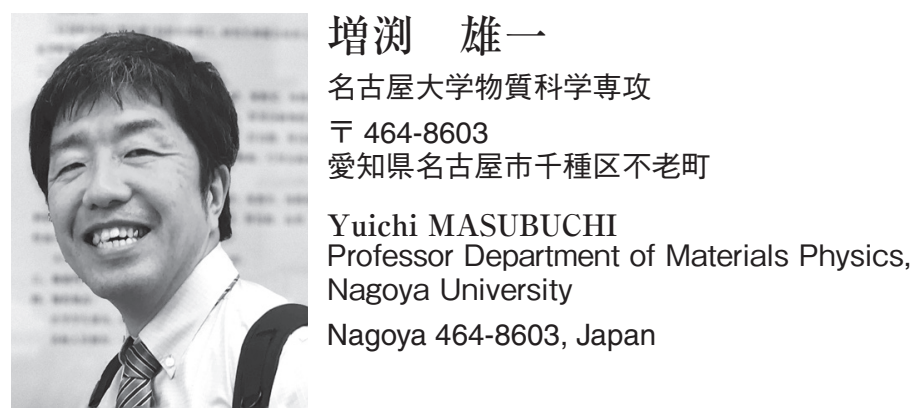

論文要旨：レオロジーのシミュレーションとは, 物質の変形/流動下での物質の応力を計算することであ る。大きく分けて，現象論的レオロジーに即した方法と，分子論的レオロジーに基づく方法がある。現象論 的な方法は構成方程式に基づくもので, レオロジー特性は与えられているものとして，プロセス中でのマク ロな挙動を計算する場合に用いられる。分子論的な方法は分子運動からレオロジー特性を導く立場で，与 えられた分子の構造からレオロジー特性を考えるために用いられる。本稿では, 主に分子論的な立場を説明 する。特に，長時間の分子運動を扱うために必要な粗視化に着目して説明する。

\begin{abstract}
One can call a simulation as "rheology simulation" if the simulation can deal with the calculation of the mechanical response of materials against flows and deformations. There exist two significant branches for such rheology simulation. In the industry, a widely used direction is the phenomenological approach, where the constitutive equation gives the rheological properties of the material. The other one is the molecular basis to calculate the rheological properties from the dynamics of the molecules. The latter will be mainly explained in this review with attention to some coarse-graining technologies, which are required to trace the molecular motion for a long time.
\end{abstract}

Key words: emulsions, polymers, suspensions, Brownian dynamics, dissipative particle dynamics

\section{1 レオロジーシミュレーションとは何か}

レオロジーとは端的に言えば物質の変形／流動と応力 の関係を議論することである ${ }^{1-3)}$ 。したがってレオロ ジーのシミュレーションを行うには，直接的には，1） 物質の変形／流動を扱えること，2）物質の応力を計算 できること，が満たされていればよい。与えた変形／流 動と, その結果として得られる応力との関係を計算から 得られるのであれば，それがレオロジーのシミュレー ションに他ならない。

レオロジーのシミュレーションには大きく分けて以下 の 2 つがある。まず，A）現象論的なレオロジーに即し た方法である。すなわち, 変形/流動と応力の関係が, 構成方程式と呼ばれる方程式で与えられており，当該の 方程式（多くは微分方程式）を必要に応じて数值的に解

連絡者：増渕 雄一

E-mail : mas@mp.pse.nagoya-u.ac.jp
く。次にB)分子論的なレオロジーに基づく方法である。 すなわち, 変形/流動の下で分子が運動する様子を数值 的に解き, 分子間の相互作用から応力を求める。

A の現象論的な方法はレオロジーそのものに対する 計算コストは小さく, 複雑な流動条件に対応できる。実 際のプロセス中でのマクロな流れを計算する場合にはこ ちらが用いられる。ただし物質の個性は構成方程式中の いくつかのパラメーターに押し込められ，それらのパラ メーターが物質中の分子の構造にどう依存するかは一般 には不明である。また，あらかじめ構成方程式がわかっ ていない材料には適用できない。このため, 事前に実験 を行うなどして, 対象とする物質のレオロジーを定式化 できていないと計算できない。

$\mathrm{B}$ の分子論的な方法は分子シミュレーションを行うの で分子の構造を考慮できる。構成方程式を用いないので, 実験をせずに計算を行うことも原理的には可能である。 ただし計算コストは大きくなる。現実的な計算のために 


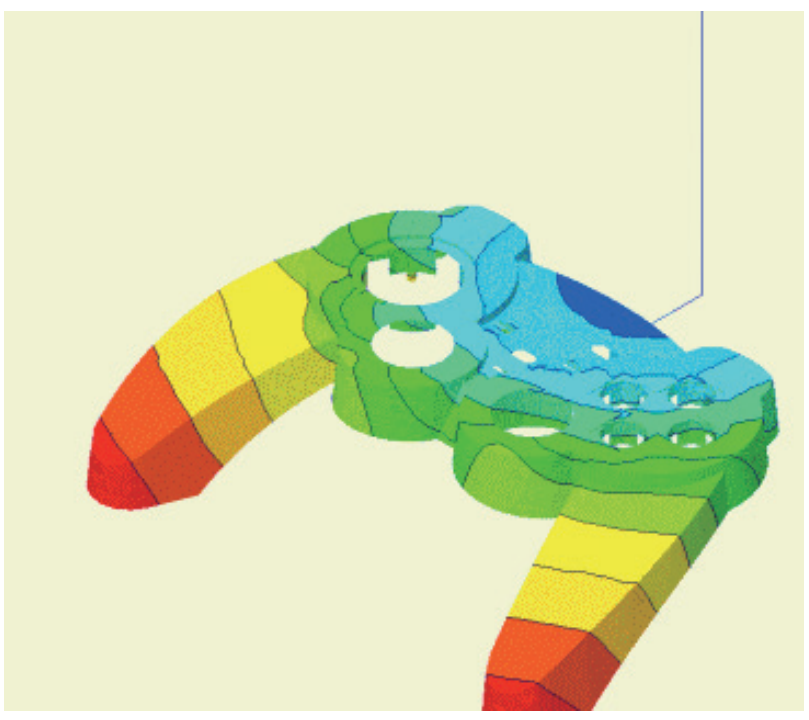

Fig. 1 プラスチックメルトの射出成形 CAE による流動解析 の例。旧プラメディア社（現在は CYBERNET 社に 吸収合併）より恵与。

は後述するような粗視化モデリングという方法を用いる 必要があることが多い。また，分子シミュレーションに おいては境界条件に制約があるため，大規模な計算を除 けば単純な流動条件にしか対応できない。

本稿では，まず $\mathrm{A}$ を簡単に説明して B との違いを明 確にした上で，主にBの立場を説明する。

\section{2 現象論的なシミュレーション}

現象論的なシミュレーションでは，レオロジーそのも の（すなわち，応力が変形／流動によってどのように変 化するか）は興味の対象ではない。当該のレオロジーを 示す液体を，複雑な流路に通した時に，どのような挙動 を示すのかが計算の主たる目的になる。

製品の製造過程を計算するプロセスシミュレーション においては現象論的な方法が広く用いられる ${ }^{4,5)}$ 。現象 論的な方法では, 粘度や応力が変形／流動によってどの ように変化するかを記述した構成方程式は既知のものと する。

例えば高分子液体やエマルションなどでは, 粘度 $\eta$ がせん断速度 $\dot{\gamma}$ の増加によって低下するシアシニング挙 動が観察される。このシアシニング挙動を表現する現象 式としてょく用いられる指数式と Carreau-Yasuda 式 ${ }^{6)}$ を以下に示す。

$$
\begin{aligned}
& \eta=\mathrm{K} \dot{\gamma}^{n-1} \\
& \frac{\eta-\eta_{\infty}}{\eta_{0}-\eta_{\infty}}=\left[1+(\lambda \dot{\gamma})^{2}\right]^{(n-1) / 2}
\end{aligned}
$$

これらの式には粘弾性は考慮されていないが, 緩和時

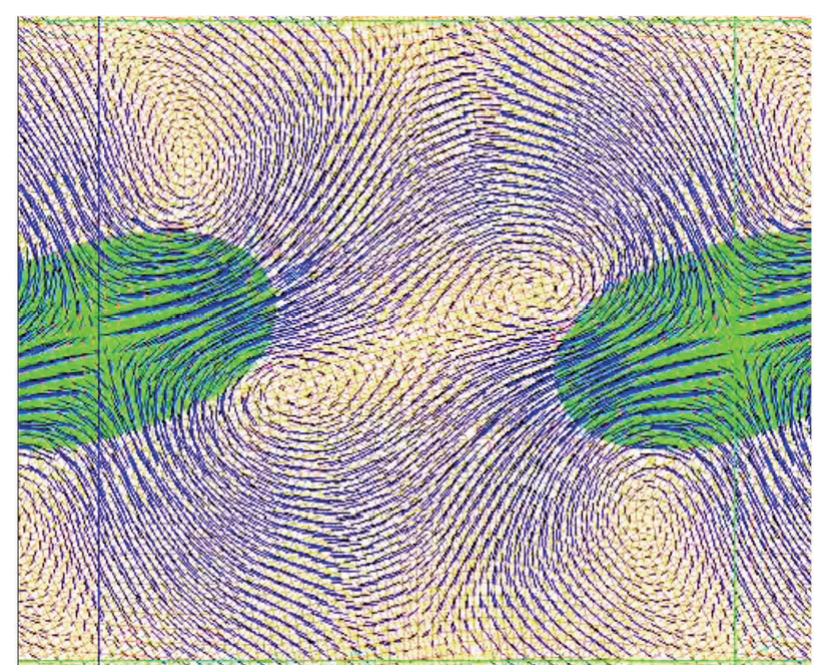

Fig. 2 エマルジョンに階段状のせん断変形を加えた後の流 動場の計算。OCTA 活用事例集 ${ }^{11,12)}$ より。

間がプロセスの特徵時間に比べて短い場合には用いるこ とができる。例えば射出成形のプラスチック成形加工 CAE どに広く用いられている。物質に依存するパラ メーター $K, \eta_{0}, \eta_{\infty}$, べき指数 $n$ は実験で求める。 $K$, $\eta_{0}, \eta_{\infty}$ は温度にも依存する。これらのパラメーターは 素材メーカーから提供される場合もある。Fig. 1 は典型 的な射出成形 $\mathrm{CAE}$ の例である。この例ではゲーム機の コントローラーのカバーを高分子メルトの射出成形でつ くる様子が計算されている。

$2 \cdot 1$ メゾスケールでの現象論的なシミュレーション

サスペンジョンやエマルジョン, 泡などの多相液体で, ブラウン運動を顕に扱わない場合には，系が含有するそ れぞれの流体に上記の現象論的なシミュレーションを応 用して，レオロジーを計算する場合がある ${ }^{7-10)}$ 。たとえ ばサスペンジョンであれば，粒子のサイズが概ね $100 \mu \mathrm{m}$ を越えれば粒子のブラウン運動は無視できるの で，流体のなかにボールが浮いている系の計算と原理的 には同じである。エマルジョンでは液滴変形における界 面張力の効果と液滴内部での流動を計算する必要があ り, 液滴の合一や分裂は簡単ではないが, マクロな流体 計算で扱うことはできる。Fig. 2 はせん断変形を受けた エマルジョンの液滴内外に発生する流れ場の計算をした ものである ${ }^{11,12)}$ 。このような計算から，系全体の応力 を求めることができる。

\section{3 分子論的なシミュレーション}

分子論的なシミュレーションでは, 物質のレオロジー 挙動そのものに興味の主体がある。すなわち, 系に変形 ／流動を与えた時にどのような応力を示すかについて， 系を構成する分子の影響を調べる。この計算では系に与 
える変形／流動は基本的に単純なものに限定する。

分子レベルのシミュレーションでは, マクロな応力は 以下のビリアル式で与えられる。

$$
\sigma_{\alpha \beta}(t)=\frac{1}{V} \sum F_{\alpha}(t) r_{\beta}(t)
$$

ここで $\sigma$ は応力テンソル, $\alpha$ と $\beta$ は $x, y, z$ を表し, $\mathrm{F}$ $=\left(F_{x}, F_{y}, F_{z}\right)$ と $\mathrm{r}=\left(r_{x}, r_{y}, r_{z}\right)$ は 2 つの原子間に働く 力と原子間の相対べクトルを示している。 れるすべての組について和を取ることを示す。 $V$ は体積 である。

式（3）は，系を構成する原子の位置がわかれば応力 がわかることを意味している。従って応力の時間変化を 知るには，原子の位置の時間変化がわかればよいことを 意味している。式（3）は変形／流動を与えた場合でも 使えるので, シミュレーションが流動／変形に対応して いれば，実験と同様に変形／流動と応力の関係（すなわ ちレオロジー）を議論することができる。

分子シミュレーションの特性として系のサイズが小さ いため, 式（3）の応力は実験に比べると非常に摇らぎ が大きい。このため精度には限界がある。逆に摇らぎを 生かして実験では困難な解析を行うことも可能である。 例えば広く用いられている方法として, 線形緩和弾性率 $G(t)$ を以下の Green-Kubo 公式から求めることがある。

$$
G(t)=\frac{V}{k T}\left\langle\sigma_{x y}\left(t_{0}+t\right) \sigma_{x y}\left(t_{0}\right)\right\rangle_{t_{0}}
$$

実験的には $G(t)$ は微小な階段状ひずみを与えたとき の応力緩和から求められるが, 式 (4) では平衡状態（つ まり変形がない状態）での応力の自己相関関数から求め られる。G(t) から, 実験と同様に, ゼロせん断粘度 $\eta_{0}$, 粘度成長曲線 $\eta^{+}(t)$, 貯蔵 / 損失弾性率 $G^{\prime}(\omega), G^{\prime \prime}(\omega)$ などの線形粘弾性量が算出可能である。

\section{$3 \cdot 1$ 分子動力学シミュレーション}

式（3）に基づいてレオロジーを計算しようとするとき， 最も直接的な方法はいわゆる分子動力学シミュレーショ ンである ${ }^{13)}$ 。分子動力学シミュレーションとは, 分子 を構成するそれぞれの原子を質点と見なし，質点の運動 をニュートンの運動方程式により数值的に解く方法であ る。すなわち，各原子の位置を $\mathrm{R}$ とすると， $\mathrm{R}$ の従う 運動方程式は以下となる。

$$
m \frac{d^{2} \mathbf{R}}{d t^{2}}=-\frac{d U}{d \mathbf{R}}
$$

ここで $m$ は原子の質量, $U$ は他の原子との相互作用 ポテンシャルである。式（5）を数值的に解いて $\mathrm{R}$ の時 間変化が得られれば，式（3）は直接計算できる。

分子動力学法を用いたレオロジーの研究は高分子や液 晶では長い歴史がある。たとえば高分子のレオロジーを
ターゲットとした計算は 1980 年代から行われており，当 初はガラス状態の高分子の応力ひずみ曲線を求める計算 が行われていた ${ }^{14)}$ 。2000 年に近づくと式 (4) を用いて 線形緩和弾性率を出す計算が行われるようになった ${ }^{15)}$ 。 一方でエマルジョンやサスペンションの研究は, $2 \cdot 1$ で述べたような計算や，以下で述べるような粗視化され た手法が主であって, 分子動力学法での計算は例がみつ けられない。これらの系では対象となる系に含まれる原 子／分子の数が膨大であることと, 何よりも緩和時間が 長大であることにより，計算コストが莫大になることが 理由である。たとえばエマルジョンの緩和時間は数秒か ら数百秒に及ぶ。分子動力学シミュレーションで一般的 に扱える原子数は百万, 時間スケールは, ナノ秒程度で あるから, その差が大きい。しかし, 本特集号の岡崎先 生の記事にあるように, 最新の計算科学技術によれば, かなりリアルな系を分子動力学シミュレーションで扱う ことができるようになってきている。

\section{$3 \cdot 2$ 粗視化と分子シミュレーション}

粗視化とは「系を構成する自由度の中で, 対象とする現 象を支配する重要な自由度を選び出すこと」である ${ }^{16)}$ 。 当該の自由度の動力学を記述するために用いられること も多い。端的な例としては, 物体の放物運動がある。高 校の物理で典型的な問題として, ボールを空中に投げ上 げたときどのような運動をするかを問うものがある。こ のときボールは質点とみなされ，ボールを構成する原子 すべての運動を考えることはない。ボールを質点とみな すことは, ボールの重心の座標を重要な自由度とみなし, 他の自由度を無視することに他ならない。これは粗視化 の例である。放物運動と並んで典型的な問題の一つに電 気回路の問題がある。直列や並列につながれたいくつか の抵抗を合成して一つの抵抗に置き換えて考える。また 流体力学においては, 本来は多数の分子のあつまりであ る流体の特徵を粘性係数で代表する。これらも粗視化で ある。このように粗視化は, 物理学, 機械工学, 化学工 学など，物質をマクロに捉える学問体系では，普通に用 いられている考え方である。2・1で説明した計算も同 様の考え方に基づいている。

いわゆるソフトマター物理学と呼ばれる分野では, 粗 視化の考え方が, 分子のようなミクロなスケールでも成 り立つ場合があるとの期待に基づいて様々な議論がなさ れる。ここでミクロとマクロの境目は，ブラウン運動を 顕に考えるか否かである。例えば Fig. 3 に示すような高 分子を考える。この分子はもちろん原子から構成されて いるが，いくつかの原子をひとまとめにして粗視化した 粒子を考えたとする（このとき，どのように粗視化した らよいかについて明確な指針はない。粗視化されたモデ 


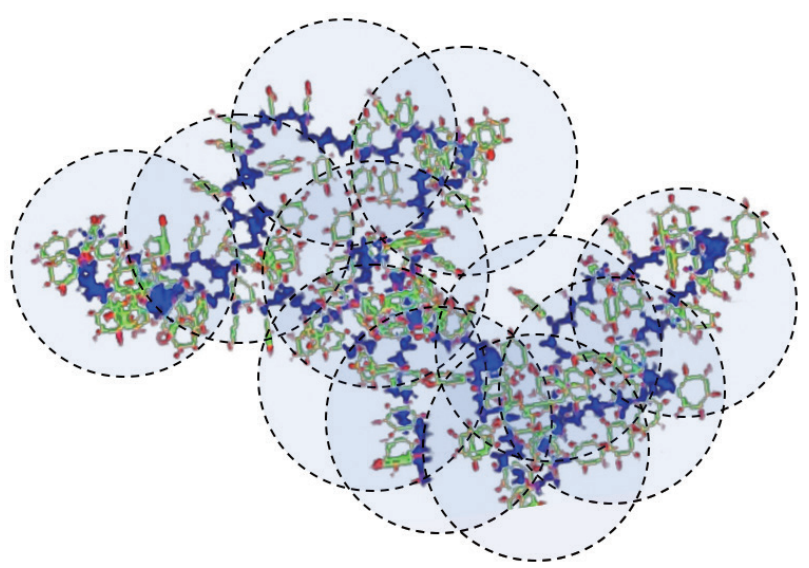

Fig. 3 ポリスチレンの全原子モデルの粗視化の例

ルを用いた計算が実験を再現すればよし，しなければモ デルを作り直す, という半経験的な作業が必要である)。

Fig. 3 のスケールでの粗視化であれば，粗視化粒子もブ ラウン運動する。

ブラウン運動が重要なスケールの粗視化では，ブラウ ン運動する粒子（微小なナノ粒子の場合もあれば，分子 の場合もある）について, その運動方程式が以下の一般 化ランジュバン方程式で書ける ${ }^{17)}$ 。

$$
m^{\prime} \frac{d^{2} \mathbf{R}^{\prime}}{d t^{2}}=-\frac{d U^{\prime}}{d \mathbf{R}^{\prime}}+\mathbf{F}_{\mathrm{D}}+\mathrm{F}_{\mathrm{R}}
$$

ここで $m^{\prime}, \mathbf{R}^{\prime}$ は粒子の質量と位置, $U^{\prime}$ は粗視化粒子 間に働く相互作用ポテンシャルである。左辺と右辺第一 項は式（5）を粗視化粒子について書いたと考えればよ い。これに加えて, 粗視化粒子の運動には, 粗視化され る前の粒子の運動を反映する項が追加される。これが右 辺の第 2 項と第 3 項である。第 2 項 $\mathrm{F}_{\mathrm{D}}$ は摩擦による散 逸を示す項で，一般に時間に依存し，等方的でなく，粒 子毎に異なり, さらに他の粒子も含む全粒子の位置と速 度に依存する。第 3 項 $\mathrm{F}_{\mathrm{R}}$ はブラウン運動を表すランダ ム力である。 $\mathrm{F}_{\mathrm{D}}, \mathrm{F}_{\mathrm{R}}$ は, その起源が同じ（粗視化前の 自由度の運動）なので, カップルしている。つまり $\mathrm{F}_{\mathrm{R}}$ も一般に時間に依存し，等方的でなく，粒子毎に異なり， 他の全粒子の位置と速度に依存する。選ばれた遅い自由 度の運動（粗視化粒子の運動）を決めるには, $m^{\prime}, U^{\prime}$, $\mathrm{F}_{\mathrm{D}}, \mathrm{F}_{\mathrm{R}}$ を決めなければならない。

粗視化粒子間の相互作用関数 $U^{\prime}$ については求めるた めの方法論が確立されてきている ${ }^{18)}$ 。ただし，ほとん どの場合に $U^{\prime}$ は粗視化粒子間の二体の相互作用として 書かれることには注意が必要である。粗視化前の状況を 考えれば，粗視化粒子間には多体の相互作用が重要な場 合もある。

一方, $\mathrm{F}_{\mathrm{D}}$ と $\mathrm{F}_{\mathrm{R}}$ については直接決めることが困難であ るため, いくつかの方法で近似されている。以下では,
近似が異なる方法を紹介する。なお，これらの方法はあ くまでも運動方程式の違いであって, 粗視化レベルの違 いを示すものではない。粗視化レベルに関係なく, どの 運動方程式を用いることもできる。ただし, 各項目に示 すように，それぞれの運動方程式に適した粗視化レベル があるように思われる。

\section{$3 \cdot 3$ 粗視化分子動力学法}

第ゼロ近似として $\mathrm{F}_{\mathrm{D}}$ と $\mathrm{F}_{\mathrm{R}}$ を無視することがある。 すなわち運動方程式を以下のように書く。

$$
m^{\prime} \frac{d^{2} \mathbf{R}^{\prime}}{d t^{2}}=-\frac{d U^{\prime}}{d \mathbf{R}^{\prime}}
$$

代表例は $\mathrm{CH}_{2}$ や $\mathrm{CH}_{3}$ を一つの質点として扱う，いわ ゆる United atom シミュレーションである ${ }^{19)}$ 。 Padding と Briels ${ }^{20)}$ の分類によると, 粗視化分子動力学法 (Coarse grained molecular dynamics : CGMD）と呼ばれる。 $\mathrm{F}_{\mathrm{D}}$ と $\mathrm{F}_{\mathrm{R}}$ を無視することの代償として, ダイナミクスは粗 視化前の結果とは異なる。しかし, まとめる原子の数が あまり大きくないときには, 粗視化前に比べて数倍の加 速が見られるだけで，この時間の加速だけを調整すれば 妥当な結果が得られることが多いようである。この加速 因子は全自由度を残した計算の結果と分子の拡散定数等 を比較することによって経験的に得ることができるが， 理論的に求める方法論は確立されていない。また，粗視 化の方法によっては，たとえば拡散定数と回転緩和時間 で加速因子が異なるようなことも起きる。

\section{$3 \cdot 4$ ブラウニアン動力学法}

次によく見られる立場は， $\mathrm{F}_{\mathrm{D}}$ と $\mathrm{F}_{\mathrm{R}}$ が等方的で，かつ 時間方向および異なる粒子間での相関を持たないとする 近似である。この場合の運動方程式は以下で書かれる。

$m^{\prime} \frac{d^{2} \mathbf{R}^{\prime}}{d t^{2}}=-\frac{d U^{\prime}}{d \mathbf{R}^{\prime}}-\zeta \frac{d \mathbf{R}^{\prime}}{d t^{2}}+\mathrm{F}_{\mathrm{R}}$

ここでらは等方的で時間に依存しない摩擦係数であ る。 $\mathrm{F}_{\mathrm{R}}$ は以下を満たす。

$$
\left\langle\mathrm{F}_{\mathrm{R}}\right\rangle=0,\left\langle\mathrm{~F}_{\mathrm{R}}{ }^{i}(t) \mathrm{F}_{\mathrm{R}}{ }^{j}\left(t^{\prime}\right)\right\rangle=6 \zeta k T \delta_{i j} \delta\left(t-t^{\prime}\right)
$$

式（8）を使う方法は Brownian Dynamics（BD）法 と呼ばれる。ただし式（7）と同じく粗視化 MD 法と呼 ばれることもある。高分子では Kremer-Grest モデル ${ }^{21)}$ がこの範疇にはいる。

$\mathrm{BD}$ 法は $\mathrm{F}_{\mathrm{D}}$ と $\mathrm{F}_{\mathrm{R}}$ を考慮している分, CGMD 法に比 べると粗視化の度合いを大きく取れる。しかし, 粒子間 に相関のない $\mathrm{F}_{\mathrm{D}}$ と $\mathrm{F}_{\mathrm{R}}$ のために, 系の運動量が保存さ れず流体相互作用を考慮できないなどの問題がある。

$\mathrm{BD}$ 法では一般に $U^{\prime}$ は Lennard-Jones 型の相互作用 を用いる。しかし計算コストが高いので, 粒子の濃度場 で置き換えて高速計算を行う手法 ${ }^{22)}$ も提案されている。 


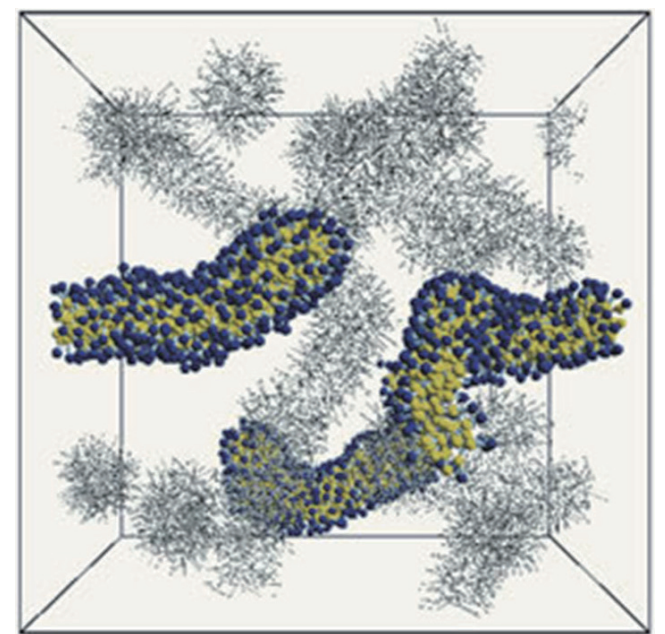

Fig. 4 DPD 法によるひも状ミセルのシミュレーション ${ }^{24)}$

\section{5 散逸粒子動力学法}

各粒子の $\mathrm{F}_{\mathrm{D}}$ と $\mathrm{F}_{\mathrm{R}}$ を粒子ごとに独立にせずに，他の 粒子の寄与を考えたものが散逸粒子動力学 (Dissipative Particle Dynamics：DPD） 法 ${ }^{23)}$ である。DPD 法の運 動方程式は以下のように書かれる。

$$
m^{\prime} \frac{d^{2} \mathbf{R}^{\prime}}{d t^{2}}=-\frac{d U^{\prime}}{d \mathbf{R}^{\prime}}+\sum_{i}\left(\mathbf{F}_{\mathrm{D}}{ }^{i}+\mathbf{F}_{\mathrm{R}}{ }^{i}\right)
$$

ここで $\mathrm{F}_{\mathrm{D}}{ }^{i}$ と $\mathrm{F}_{\mathrm{R}}{ }^{i}$ は，今考えている粗視化粒子とは別 の粒子 $i$ との相対距離/相対速度で決まる散逸力とラン ダム力で，全粒子の寄与が入っている。DPD 法は BD 法に対して系の運動量が保存される点が優れており，流 体力学的相互作用が自然に考慮される。DPD 法は界面活 性剤の構造形成などに用いられ，エマルジョンの計算に も用いられる。Fig. 4 にひも状ミセルの計算例を示す ${ }^{24)}$ 。 DPD 法では $2 \cdot 1$ で述べた方法よりも計算コストはかか るが，例えば界面張力の場所による不均一性や時間変化 を直接取り入れることができる。

$\mathrm{DPD}$ 法は $\mathrm{F}_{\mathrm{D}}$ と $\mathrm{F}_{\mathrm{R}}$ の扱いが CGMD 法や $\mathrm{BD}$ 法に比 べて優れているために，それらの手法に比べると粗視化 の度合いを大きく取れる。粗視化度を大きくすると，系 の密度を保つために粒子間の重なりを許す必要があるた め，U'にはソフトな相互作用が用いられる。

\section{3・6 ストークス動力学法}

サスペンジョンの計算をするために開発された Stokesian Dynamics（SD） 法 ${ }^{25)}$ は, BD 法と DPD 法の中間 の立場をとる。すなわち， $\mathrm{F}_{\mathrm{D}}$ は流体力学的相互作用を 通して生ずる他の粒子の寄与を考えて計算される一方, $\mathrm{F}_{\mathrm{R}}$ はそれぞれの粒子について独立とする。粒子の運動 方程式を形式的に式で表すと以下のようになる。

$$
m^{\prime} \frac{d^{2} \mathbf{R}^{\prime}}{d t^{2}}=-\frac{d U^{\prime}}{d \mathbf{R}^{\prime}}+\sum_{i} \mathrm{~F}_{\mathrm{D}}{ }^{i}+\mathrm{F}_{\mathrm{R}}
$$

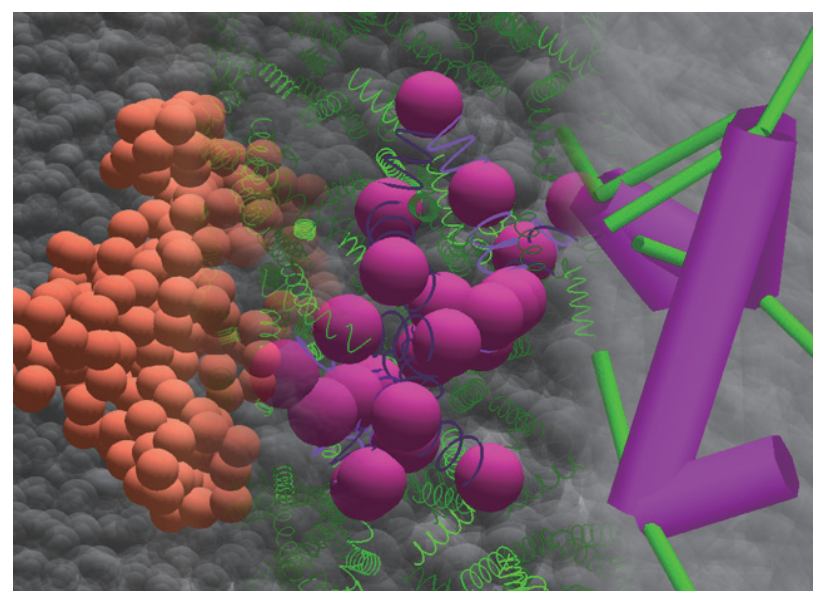

Fig. 5 高分子のからみあいを考慮した種々の粗視化モデル。 互いに等価な高分子を表現している。

オリジナルの SD 法では $\mathrm{F}_{\mathrm{D}}$ の計算に大幅な近似がな されていたが，粒子周りの流体の運動をより正確に扱う ための手法も開発されている ${ }^{26,27) 。 ~}$

$\mathrm{SD}$ 法はサスペンジョン中の粒子の運動を計算するの に用いられるほか, 溶液中の高分子の運動にも適用され ることもある。DPD 法では溶媒の流体も粒子として考 える必要があるが, SD 法では溶媒はあらわに考えない。 このため DPD 法よりも計算コストは抑えられる。

\section{$3 \cdot 7$ 高分子のからみあい}

高分子の溶融体や濃厚溶液を計算する場合には「から みあい効果」を考慮する必要がある 28-33)。からみあい とは，高分子どうしが幾何学的にすり抜けられないため に発生する，分子運動に対する動的な束縛をさす。この 効果は, 分子動力学法や粗視化度が低い CGMD 法, BD 法など，粒子間の重なりを許さないレベルで粗視化され たモデルを用いる方法であれば，自動的に入っている。 しかし，ソフトな相互作用を用いた BD 法や DPD 法で は，分子が互いにすり抜けるので，からみあい効果が入 らない。この問題を解決するためにいくつかの方法が提 案され，それぞれ成功を収めている。例えば純粋に幾何 学的に高分子間のすり抜けを検出し，それを許さないよ うに分子を動かす方法 ${ }^{34)}$ は直感的に理解しやすい。

相互作用に頼らずにからみあい効果を表現する方法と して有名なものが管理論 ${ }^{35)}$ である。管理論では, 高分 子は自らの鎖に沿った方向の拡散運動が支配的であると 仮定し, それ以外の方向への運動を考えない。分子鎖に 沿った方向の運動は BD 法の運動方程式で表す。粗視化 ポテンシャル U'としては分子内結合相互作用のみを考 え, 分子間相互作用は考慮しない。管理論は多数の分子 の運動を管中の 1 つの高分子の運動に置き換えて考え る。よって分子運動とその結果生じるレオロジーは, 分 子シミュレーションによらずに解析的に求められてい 
る。

管理論と通常の多体シミュレーションの間に位置する モデルも開発されている。例えば多体スリップリンクモ デル ${ }^{36)}$ では相互作用のない鎖をスリップリンクと呼ば れる拘束で接続して互いの運動を束縛することでからみ あいを表現する。多体スリップスプリングモデル ${ }^{37}$, 38) においては相互作用のない鎖を仮想的なバネで結合して からみあい編み目を形成する。Fig. 5 は, Kremer-Grest モデルとこれらのモデルで同じ分子量の高分子をモデル 化したときの比較である。からみあいをうまくモデル化 できると粗視化の度合いを大きくできるので，計算コス 卜を劇的に下げることが可能になる。また線形／非線形 粘弾性も定量的に再現できる。

\section{文 献}

1）講座・レオロジー。日本レオロジー学会編, 高分子刊 行会 (1992).

Lecture/Rheology. Japan Society of Rheology ed., Kobunshi Shuppankai (1992).

2）尾崎邦宏.レオロジーの世界. 森北出版（2011） Ozaki, K. World of Rheology. Morikita Publishing Co., Ltd. (2011).

3）増渕雄一。おもしろレオロジー。技術評論社（2010）. Masubuchi, Y. Interesting rheology. Gijutsu-Hyohron Co., Ltd. (2010).

4) Zheng, R.; Tanner, R. I.; Xi-Jun, F. Injection Molding: Integration of Theory and Modeling Methods. Springer (2011).

5) Agassant, J.-F.; Mackley, M. R. Principles of Polymer Processing Modelling. MATEC Web Conf. 80, 11002 (2016)

6) Yasuda, K.; Armstrong, R. C.; Cohen, R. E. Shear Flow Properties of Concentrated Solutions of Linear and Star Branched Polystyrenes. Rheol. Acta 20, 163-178 (1981).

7) Ladd, A. J. Numerical Simulations of Particulate Suspensions Via a Discretized Boltzmann Equation. Part 1. Theoretical Foundation. J. Fluid Mech. 271, 285-309 (1994).

8) Koelman, J. M. V. A.; Hoogerbrugge, P. J. Dynamic Simulations of Hard-Sphere Suspensions under Steady Shear. Epl. 21, 363-368 (1993).

9) Li, J.; Renardy, Y. Y.; Renardy, M. Numerical Simulation of Breakup of a Viscous Drop in Simple Shear Flow through a Volume-of-Fluid Method. Phys. Fluids 12, 269-282 (2000).

10) Fischer, P.; Erni, P. Emulsion Drops in External Flow Fields-The Role of Liquid Interfaces. Curr. Opin. Colloid Interface Sci. 12 (4-5), 196-205 (2007).

11）新化学技術推進協会. 高分子材料シミュレーション： OCTA 活用事例集．化学工業日報社（2014）。

New chemical technology promotion association. Polymer material simulation-OCTA application casebook-
The Chemical Daily Co., Ltd. (2014).

12) JACI. Computer Simulation of Polymeric Materials. Chemical Innovation, J. A. for (Ed.). Springer, Singapore (2016).

13）岡崎進 ; 吉井範行. コンピュータ・シミュレーション の基礎 (第 2 版)：分子のミクロな性質を解明するため に. 化学同人 (2011).

Okazaki, S.; Yoshii, N. Basics of computer simulation (2nd ed.)-To elucidate the microscopic properties of molecules. Kagaku-Dojin Publishing Company, INC. (2011).

14) Theodorou, D. N.; Suter, U. W. Atomistic Modeling of Mechanical Properties of Polymeric Glasses. Macromolecules 19, 139-154 (1986).

15) Harmandaris, V. A.; Mavrantzas, V. G.; Theodorou, D. N. Atomistic Molecular Dynamics Simulation of Stress Relaxation upon Cessation of Steady-State Uniaxial Elongational Flow. Macromolecules 33, 8062-8076 (2000).

16) Doi, M. Soft Matter Physics. Oxford University Press (2013).

17) Seifert, U. Stochastic Thermodynamics, Fluctuation Theorems and Molecular Machines. Reports Prog. Phys. 75, 126001 (2012).

18) Müller-Plathe, F. Coarse-Graining in Polymer Simulation: From the Atomistic to the Mesoscopic Scale and Back. ChemPhysChem 3, 754-769 (2002).

19) Rigby, D.; Roe, R. Molecular Dynamics Simulation of Polymer Liquid and Glass. I. Glass Transition. J. Chem. Phys. 87, 7285-7292 (1987).

20) Padding, J. T.; Briels, W. J. Systematic Coarse-Graining of the Dynamics of Entangled Polymer Melts: The Road from Chemistry to Rheology. J. Phys. Condens. Matter 23, 233101 (2011).

21) Kremer, K.; Grest, G. S. Dynamics of Entangled Linear Polymer Melts: A Molecular-Dynamics Simulation. J. Chem. Phys. 92, 5057-5086 (1990).

22) Milano, G.; Kawakatsu, T. Hybrid Particle-Field Molecular Dynamics Simulations for Dense Polymer Systems. J. Chem. Phys. 130, 214106 (2009).

23) Groot, R. D.; Warren, P. B. Dissipative Particle Dynamics: Bridging the Gap between Atomistic and Mesoscopic Simulation. J. Chem. Phys. 107, 4423-4435 (1997).

24) Arai, N.; Yasuoka, K.; Masubuchi, Y. Spontaneous SelfAssembly Process for Threadlike Micelles. J. Chem. Phys. 126, 244905 (2007).

25) Brady, J. F. The Rheological Behavior of Concentrated Colloidal Dispersions. J. Chem. Phys. 99, 567-581 (1993).

26) Yamamoto, R.; Nakayama, Y.; Kim, K. A Method to Resolve Hydrodynamic Interactions in Colloidal Dispersions. Comput. Phys. Commun. 169, 301-304(2005) .

27) Tanaka, H.; Araki, T. Simulation Method of Colloidal Suspensions with Hydrodynamic Interactions: Fluid Particle Dynamics. Phys. Rev. Lett. 85, 1338-1341 
(2000).

28) Masubuchi, Y. Simulating the Flow of Entangled Polymers. Annu. Rev. Chem. Biomol. Eng. 5, 11-33(2014).

29) Masubuchi, Y. Molecular Modeling for Polymer Rheology. in Reference Module in Materials Science and Materials Engineering. Elsevier, pp. 1-7 (2016).

30）増㴊雄一. 高分子成形加工の分子シミュレーション. 日本機械学会計算力学部門ニュースレター 44, 14-15 (2010).

Masubuchi, Y. CMD Newsletter No. 44, 14-15 (2010).

31）増㴊雄一. 高分子ダイナミクスのシミュレーション. 高分子 60, 85-88 (2011).

Masubuchi, Y. POL YMERS (The Society of Polymer Science, Japan) 60, 85-88 (2011).

32）増㴊雄一. 高分子材料のレオロジーの分子シミュレー ション．日本ゴム協会誌 86 (4)，113-118（2013）.

Masubuchi, Y. NIPPON GOMU KYOKAISHI (THE SOCIETY OF RUBBER SCIENCE AND TECHNOLOGY, JAPAN) 86 (4), 113-118 (2013).

33）増㴊雄一. 高分子のからみあいと分子シミュレーショ ン.アンサンブル 17 (3), 162-166（2015）.
Masubuchi, Y. Ensemble (The Molecular Simulation Society of Japan) 17 (3), 162-166 (2015).

34) Padding, J. T.; Briels, W. J. Uncrossability Constraints in Mesoscopic Polymer Melt Simulations: Non-Rouse Behavior of $\mathrm{C}_{120} \mathrm{H}_{242}$. J. Chem. Phys. 115, 2846-2859 (2001).

35) Doi, M.; Edwards, S. F. The Theory of Polymer Dynamics. Clarendon press, Oxford (1986).

36) Masubuchi, Y.; Takimoto, J.-I.; Koyama, K.; Ianniruberto, G.; Marrucci, G.; Greco, F. Brownian Simulations of a Network of Reptating Primitive Chains. J. Chem. Phys. 115, 4387-4394 (2001).

37) Uneyama, T.; Masubuchi, Y. Multi-Chain Slip-Spring Model for Entangled Polymer Dynamics. J. Chem. Phys. 137, 154902 (2012).

38) Langeloth, M.; Masubuchi, Y.; Böhm, M. C.; Müllerplathe, F. Recovering the Reptation Dynamics of Polymer Melts in Dissipative Particle Dynamics Simulations via Slip-Springs. J. Chem. Phys. 138, 104907 (2013). 